The death of Europe? Continental fates after Ukraine RICHARD SAKWA

On the outbreak of the First World War, Pope Benedict XV declared that the conflict represented 'the suicide of Europe'. ${ }^{1}$ A hundred years later we can talk of a new suicide, as the idealism associated with a whole era of European unification has been disappointed. European integration of a narrow and exclusive sort, of course, continues, but the transformatory goal of bringing together the continent on the basis of peace and justice has run into the sands. At the heart of the European Union (EU) is a peace project, and it spectacularly delivered on this promise in Western Europe before 1989. However, when faced with a no less demanding challenge in the post-communist era - to heal Cold War divisions and to build the foundations for a united continent - the EU evidently failed. Instead of embodying a vision embracing the whole continent, the EU is in danger of becoming little more than the civilian wing of the Atlantic security alliance. Critics argue that even its increasingly limited commitment to social and crossnational solidarity is jeopardized by the planned Transatlantic Trade and Investment Partnership (TTIP). The post-Cold War order has unravelled in numerous ways, and it is the purpose of this article to examine aspects of the European dimension to this breakdown. ${ }^{2}$ In this article the putative 'death of Europe' is defined in three ways. The first is the exhaustion of the aspirations codified in the Charter of Paris for a New Europe, adopted at the second Conference on Security and Cooperation in Europe (CSCE) summit of heads of government, meeting in Paris between 19 and 21 November 1990. The preamble unequivocally declared: 'The era of confrontation and division of Europe has ended. We declare that henceforth our relations will be founded on respect and co-operation.' Commitment to democracy, human rights and the rule of law were accompanied by respect for national sovereignty. The document insisted that

\footnotetext{
${ }^{1}$ Benedict XV called for an 'end to this most disastrous war' in Ad beatissimi apostolarum, 'Appealing for peace', 1 Nov. 1914, http://w2.vatican.va/content/benedictxv/en/encyclicals/documents/hf_ben-xv_enc_01111914_ad-beatissimi-apostolorum.html, accessed 5 April 2015.

${ }^{2}$ For a broad overview, see Rajan Menon and Eugene B. Rumer, Conflict in Ukraine: the unwinding of the post-Cold War Order (Boston: MIT Press, 2015).
} 
'Europe whole and free is calling for a new beginning'. ${ }^{3}$ The second is the transformation of the EU from a peace project based on an identifiable civilian agenda to a competitive geopolitical actor in which its own raison d'état competes with its normative commitments. The contentious absorption of territory and the struggle to create a zone of influence that displaces the previous orientations of states looks like the classic behaviour of an imperial power, although of a distinctive 'neo-medieval' rather than the classic Westphalian sort. ${ }^{4}$ The expansionist drive is generated by external demand as well as by classical imperatives to ensure security by neutralizing threats emanating from contested borderlands. Third, although Europe is certainly not to be identified with the EU, there is a broader crisis in the development of European continentalism. This is the vision of some form of 'common European home', to use the term introduced and outlined by Mikhail Gorbachev in his address to the Parliamentary Assembly of the Council of Europe in Strasbourg on 6 July 1989, stretching from Lisbon to Vladivostok. ${ }^{5}$ Instead, in the western part of the continent a 'new Atlanticism' is taking shape, combining the EU, NATO and American power, ranged against Russia and its allies in 'Euro-Asia'. These three issues are overlapping and interlocked; together, they signal the danger of Europe's becoming once again the 'dark continent', a characterization that a whole generation believed to have been transcended. ${ }^{6}$

Russia, as so often, is the uncomfortable 'other'. Even when weak and poor in the 1990s, it continued to claim the status of a Great Power, as demonstrated in its combination of competitive

\footnotetext{
${ }^{3}$ Organization for Security and Co-operation in Europe, Charter of Paris for a New Europe (Paris, 21 Nov. 1990, http://www.osce.org/node/39516, accessed 5 April 2015.

${ }^{4}$ Jan Zielonka, Europe as empire: the nature of the enlarged European Union (Oxford: Oxford University Press, 2007), and 'Europe as a global actor', International Affairs 84: 3, May 2008, pp. 471-84.

5 Mikhail Gorbachev, 'Europe as a common home', Strasbourg, 6 July 1989, http://polsci.colorado.edu/sites/default/files/1A_Gorbachev.pdf, accessed 5 April 2015.

${ }^{6}$ Mark Mazower, Dark continent: Europe's twentieth century (London: Penguin, 1999).
} 
and cooperative behaviour in the Balkans. ${ }^{7}$ When stronger and richer in the 2000 s, its assertion of this status with increasing confidence challenged the Atlantic system's claim to be benign, progressive and universal. No formula was found to bring Russia into the expanding Atlantic system, although this was not for want of trying. Russia was treated as an 'other' because ultimately it was not a straightforward rank-and-file member of the expanding Euro-Atlantic alliance system. ${ }^{8}$ At no point in its history since shaking off the 'Mongol yoke' in 1480 has Russia subordinated itself to an external power. From the western perspective, Russia's combination of domestic governance problems, including the brutal suppression of the insurgency in Chechnya in two savage wars, and threats to the sovereignty and integrity of its neighbours, rendered it an unstable and ultimately a threatening force. ${ }^{9}$ From the Russian perspective, the country had quite legitimate security interests in its neighbourhood and in the region as a whole, and since it had initiated the end of the Cold War it deserved to become an equal partner in a restructured European security community. These views were not necessarily incompatible, and until the mid-2000s all sides sought to find a way to reconcile the divergent concerns. The question that needs to be addressed is why these attempts failed so spectacularly. The conflict in Ukraine that erupted in 2014 is the most vivid manifestation of the failure to create a stable and durable European security order, but ultimately it is only a symptom of that failure. This article will not go into the details of Ukrainian events, which I have analysed

\footnotetext{
${ }^{7}$ For an exploration of Russian 'greatpowerness', see Hanna Smith, Russian greatpowerness: foreign policy, the two Chechen wars and international organisations (Helsinki: University of Helsinki Faculty of Social Sciences, 2014).

${ }^{8}$ Vladimir Baranovsky, ed., Russia and Europe: the emerging security agenda (Oxford, Oxford University Press/Stockholm International Peace Research Institute, 1996), and 'Russia: a part of Europe or apart from Europe?', International Affairs 76: 3, May 2000, pp. 443-58.

${ }^{9}$ For an exploration of these issues, see Iver B. Neumann, 'Russia as a Great Power, 18152007', Journal of International Relations and Development 11: 0\{?\}, 2008, pp. 128-51, and 'Entry into international society reconceptualised', Review of International Studies 37: 2, 2011, pp. $463-84$.
} 
elsewhere, ${ }^{10}$ but will instead provide a framework for the analysis of the palpable and dangerous breakdown of the post-Cold War European security order. In place of the standard and, in my view, inadequate arguments concerning Russian expansionist motivations for its Ukraine policy, I will outline a more complex structural approach $\{\mathbf{1}\}$. The failure to create a mutually acceptable European security system derived from the asymmetrical end of the Cold War and gave rise to the quarter-century of what President Boris Yeltsin identified as early as December 1994 as the 'cold peace'. ${ }^{11}$ Systemic tensions (the 'regime question', in other words, the nature of the Russian political system and its compatibility with Western liberal democracies, $\{2\}$ accompanied by 'values' issues), incompatible identities, struggles for hegemony, institutional inertia and differing visions of the future combined to disappoint those who believed that Europe had finally put an end to its internal divisions, and thereby to the spectre of war on the continent.

\section{The end of illusions}

There has been no shortage of warnings that the post-Cold War peace order in Europe was fragile, exclusive and unsustainable. There were clear elements of what E. H. Carr identified in the interwar period as the 'twenty years' crisis', with advocacy of peace and normative agendas accompanied by a new version of the punitive dynamic of the Treaty of Versailles of June 1919. ${ }^{12}$ Despite the noble declarations at the end of the Cold War, Russian commentators have endlessly pointed out precisely that 'Versailles' element in the new peace system. This viewpoint is eloquently summarized by Sergei Karaganov, Dean of the Faculty of World Economy and International Affairs at the Higher School of Economics in Moscow and Honorary Chairman of

\footnotetext{
${ }^{10}$ Richard Sakwa, Frontline Ukraine: crisis in the borderlands (London and New York: I. B.
} Tauris, 2015).

${ }^{11}$ Norman Kempster and Dean E. Murphy, 'Broader NATO may bring "cold peace”, Yeltsin warns: Europe: Russian President accuses U.S. of being power hungry. Speech comes as nations finalize nuclear treaty', Los Angeles Times, 6 Dec. 1994, http://articles.latimes.com/1994-1206/news/mn-5629_1_cold-war, accessed 5 April 2015.

12 Richard Sakwa, “'New Cold War" or twenty years' crisis?: Russia and international politics', International Affairs 84: 2, March 2008, pp. 241-67. 
the Council on Foreign and Defence Policy (SVOP). Explaining the breakdown in relations between Russia and the West\{3\} in 2014, he argues:

<ext>The main reason for Russia's turn is the West's refusal to recognize the place in European and global politics, which Moscow considers natural and legitimate. The West has been trying to act as a victor while refusing to accept this position of Russia, and to pursue a Versailles policy de facto, albeit in 'velvet gloves'; that is, avoiding direct annexations and reparations $\{\mathbf{4}\}$ but continuously limiting Russia's freedom, spheres of influence and markets and at the same time expanding the area of its own political and military zone of control through NATO enlargement, and its political and economic zone of influence through EU expansion. ${ }^{13}$ <extend> $<\mathrm{fl}>$ This is a classic expression of the asymmetrical end of the Cold War. In Karaganov's view, Russia was treated as a defeated power, even though the country did not see itself as such, and was assigned a modest role in world affairs. In the end, he insists, this provoked a type of 'Weimar syndrome' in a country whose dignity and interests had been ignored.

The argument has become standard across the Russian political spectrum, with the exception of a marginalized group of liberal westernizers. It has been advanced by none other than Gorbachev, the architect of the end of the Cold War. As early as 2000 he noted: 'Apparently, the West is incapable of dealing in a reasonable way with the results of the new thinking that freed the world from bloc politics and total confrontation.' ${ }^{14}$ This prompted him to endorse President Vladimir Putin's policies in 2014, including 'reunification' with Crimea, signalling the end of the era of optimism born of perestroika in the late 1980s. From this perspective, at the end of the Cold War the West had lacked a grand strategy to unite the continent, and instead had continued through inertia to extend its own institutions and structures. Russia ultimately was considered too weak and too marginal to force a substantive change, and by the time Russia became stronger, it was already too late. ${ }^{15}$

13 Sergei Karaganov, '2014: Predvaritel'nye itogi', Rossiiskaya gazeta, 28 Nov. 2014, p. 11. ${ }^{14}$ Mikhail Gorbachev and Daisaku Ikeda, Moral lessons of the twentieth century: Gorbachev and Ikeda on Buddhism and communism (London: I. B. Tauris, 2005), p. 147. The original Russian version was published in 2000.

${ }^{15}$ For a useful overview, see Edward W. Walker, 'Between East and West: NATO enlargement and the geopolitics of the Ukraine crisis', in Agnieszka Pikulicka-Wilczewska and Richard 
It was ultimately no accident that the new Sarajevo would be found in Kyiv. Russia and Ukraine had long been on divergent paths of development, with the predominant model of Ukrainian nation-building predicated on separation from Moscow. In Russia, Putin had imposed a new 'social contract' on the oligarchs, humbled the 'barons' in the regions and enjoyed an extended period of booming energy rents, whereas Ukraine every few years endured societal upheaval and political crisis in a system distorted by oligarchic power. By the time Putin returned to the presidency in May 2012 Russia was much stronger, and ready to assert itself in world politics. What Clifford Gaddy and Barry Ickes represent in structural terms as the 'missing quadrant' was being filled in: a strong but 'bad' Russia, not the weak and good Russia of the 1990s, the weak and bad Russia presented by its critics, or the good and strong Russia extolled by its friends. ${ }^{16}$ In response to the problems exposed by the 'five-day' Georgian war of August 2008, the armed forces became the object of a grand programme of reform and re-equipping. Russia under Putin presented itself as not so much anti-western as a complement to the West: a type of "neorevisionism' that sought not to change the fundamentals of international order but to ensure that Russia and other 'rising' powers were treated as equals in that system.

A very different narrative is advanced in the West. This is put most eloquently by Ivan Krastev and Mark Leonard, who argue that the events of March 2014 (the annexation and/or repatriation $\{\mathbf{5}\}$ of Crimea) signalled the retreat of Europe's post-modern order and the end of the post-Cold War European order in general. ${ }^{17}$ In this analysis, old ideas about the balance of power, imperial aggrandizement and the practices of geopolitics had come to an end, to be replaced by the interpenetration of domestic and foreign policy matters, the increasing porosity of borders, and universalistic ambitions to apply the new normativity to the rest of the world. The

Sakwa, eds, Ukraine and Russia: people, politics, propaganda and perspectives, E-International Relations, 6 March 2015, pp. 141-54, http://www.e-ir.info/2015/03/06/edited-collection-ukraineand-russia-people-politics-propaganda-perspectives/, accessed 5 April 2015.

${ }^{16}$ Clifford G. Gaddy and Barry W. Ickes, 'Ukraine, NATO enlargement and the Geithner doctrine', 10 June 2014, http://www.brookings.edu/research/articles/2014/06/10-ukraine-natogeithner-doctrine-gaddy-ickes, accessed 5 April 2015.

${ }^{17}$ Ivan Krastev and Mark Leonard, The new European disorder (London: European Council on Foreign Relations, Nov. 2014), p. 1. 
European project, in this reading, is both 'exceptional and universal', which 'made it impossible for Europeans to accept any alternative integration projects in their continent'. Locked in their 'post-modern ecosystem, Europeans lost their curiosity about how Russia sees the world and its place in it'. ${ }^{18}$ Above all, blinded by its own success, 'the EU also failed to grasp that what they saw as a benevolent—almost herbivorous— power could be viewed by others as a threat'. ${ }^{19}$ This, too, is a structural reading of the divergence in perspectives and identity between the EU and Russia. The substantive claim to normative superiority undermined the EU's ability to engage with others in Europe on the basis of sovereign equality. The EU, like the Atlantic system as a whole, became increasingly 'hermetic'-insulated from the genuine need to engage with the concerns of others by the grandeur of its own internal project (and the no less grand scale of its own internal challenges).

This meant that diplomacy, in the traditional sense of a process of give-and-take to achieve a bargaining outcome that is reasonably satisfactory to both parties, gave way to the one-way channelling of already agreed postulates. Specifically, the current 35 chapters of the acquis communautaire facing countries seeking accession to the EU can be modified only, at most, at the margins. For most countries enthusiastic about membership, this model represents a welcome liberation from their own burden of history, malfeasance and poor governance. However, this model of 'external governance' is potentially hazardous when applied, however residually, to countries who whether by choice or necessity are not candidates. ${ }^{20}$ The political subjectivity of others is inevitably denigrated if they fail to subordinate themselves to the EU's logic of normative superiority, precluding the normal diplomatic intercourse between two sovereign entities. Thus the focus of international relations is shifted to the systemic level. This is accompanied by endless controversies about 'values', which to the country at the receiving end

\footnotetext{
${ }^{18}$ Krastev and Leonard, The new European disorder, p. 2.

${ }^{19}$ Krastev and Leonard, The new European disorder, p. 3.

${ }^{20}$ Sandra Lavenex, 'EU external governance in "wider Europe", Journal of European Public

Policy 11: 4, 2004, pp. 680-700; Sandra Lavenex and Frank Schimmelfennig, 'EU rules beyond EU borders: theorizing external governance in European politics', Journal of European Public
}

Policy 16: 6, 2009, pp. 791-812. 
appears intrusive and ultimately less about concern over human rights than about the assertion of normative hegemony.

For Russia this shift in the conduct of international politics proved disastrous. Caught up in an extended period of post-communist transformation and marred by grave governance problems, Russia would inevitably score badly on this scale. Not surprisingly, its leadership sought to separate domestic issues from foreign relations, but for the EU the holistic approach is the very essence of its engagement with European states. ${ }^{21}$ Russia's resentment at being treated in this way, and its appeal to normative pluralism, consigned it in the EU's eyes - quite logically from the latter's perspective - to the category of the regressive and unenlightened. For Russia, its critique of western 'hegemonism', 'double standards' and the asymmetrical quality to the postCold War peace was considered something objective and totally separate from domestic issues. These incompatible readings of the structure of international politics generated the 'values' gap that in the end torpedoed substantive productive relations. This fundamental contradiction in European development was exacerbated by the absence of any mode of reconciliation between the different perspectives. The structural contradictions were not mediated by diplomacy, a return to the nineteenth-century Concert of Powers, Yalta-style summitry, or even the dense network of international governance, epitomized above all by the United Nations. It was this combination of conditions that led in the end to the crisis of 2014 and the breakdown of the European security order.

\section{Two visions of Europe}

Two visions of Europe have long been in contention. Timothy Garton Ash identified a clash within the EU between Euro-Atlanticism and Euro-Gaullism; ${ }^{22}$ however, the tension is not

\footnotetext{
${ }^{21}$ On contrasting identity issues, see Viatcheslav Morozov, 'Europe: self-alignment in time and space', Russia in Global Affairs, 9 Aug. 2008, http://eng.globalaffairs.ru/number/n_11285, accessed 5 April 2015; and, for a more extensive analysis, the same author's Russia's postcolonial identity: a subaltern empire in a Eurocentric world (London: Palgrave Macmillan, 2015).

${ }^{22}$ Timothy Garton Ash, Free world: why a crisis of the West reveals the opportunity of our time (London: Penguin, 2005).
} 
confined to the debate within the EU but represents a cleavage between two very different representations of Europe that profoundly affects the quality of political relations among the key actors. The first is wider Europe, the idea of the continent centred on the EU. European space is represented as Brussels-focused, with concentric rings emanating from the west European heartlands of European integration. In the 1950s this was a project designed to ensure that France and Germany would never again come to war, accompanied by a vision of a 'social Europe' motivated by Roman Catholic social philosophy. What became the EU was inspired by two fundamental ideas: to transcend the logic of conflict while restoring the statehood of its members; and to ensure equitable well-being for its citizens. Since the signing of the Treaty of Rome by the six founding members of the European Economic Community on 25 March 1957, the association has grown to encompass at present 28 members, with the latest entrants coming from the former communist part of the continent. The wider Europe is at the same time deeply embedded in the Atlantic community, which for good or ill obscures the specifically European component.

The east European countries sought liberal democracy, market reform and, above all, the 'return to Europe'. The accession wave of May 2004 included not only the central and east European states of Poland, Hungary, the Czech Republic, Slovakia and Slovenia, but also the Baltic republics of Estonia, Latvia and Lithuania (together with the Republic of Cyprus and Malta); these were joined in 2007 by Bulgaria and Romania, and in July 2013 by Croatia. There were domestic debates, setbacks and contradictions, but overall a remarkable public consensus prevailed. Political, social and geopolitical goals coincided, allowing all these countries to join the expanded Atlantic community over a remarkably short period of time. This was an exemplary manifestation of the 'wider Europe' model of development, and it has undoubtedly delivered substantial (although not always uncontested) benefits to the countries concerned. It is these benefits that Georgia, Moldova and Ukraine now seek, although in these contested 'lands in between' there is no longer the same coincidence of domestic aspirations and geopolitical orientations. The 'European choice' is, paradoxically, precisely not European-it is Atlanticist. The EU-centred wider Europe is becoming subsumed into the Atlantic system, compromising in the view of critics its own normative foundations and imbuing its policies with a geopolitical dynamic that the EU had been established precisely to transcend. 
Wider Europe is challenged by a second vision: the idea of greater Europe. Even before the disintegration of the Soviet Union in 1991, Gorbachev had issued the manifesto for this model of Europe when he spoke of the 'common European home'. This would be a continent united in its systemic diversity, since at the time when Gorbachev introduced the concept he believed that the Soviet Union would develop on the basis of a 'humane, democratic socialism'. Instead of concentric rings emanating from Brussels, weakening at the edges but nevertheless focused on a single centre, the idea of greater Europe posits a multipolar continent, with more than one centre and without a single ideological flavour. ${ }^{23}$ Thus Moscow, Ankara and, possibly, Kyiv would be centres in their own right, allied with wider Europe but retaining a multidimensional set of interactions of their own. This is a more pluralistic representation of European space, and draws on a long tradition from Giuseppe Mazzini's idea of a 'United States of Europe' through Richard Coudenhove-Kalergi's notion of pan-Europa between the world wars, Gaullist ideas of a broader common European space from the Atlantic to the Pacific, Gorbachev's dream of a common European home transcending the bloc politics of the Cold War era, Nicholas Sarkozy's return to the idea of pan-Europa, ${ }^{24}$ and the Valdai Club's idea of a 'Union of Europe'. The 'greater Europe' idea also has deep popular and elite resonance in the three Slavic countries in the borderlands of Europe (Russia, Ukraine and Belarus) $\{\mathbf{6}\}$, where it is complemented by discourses of 'Europe' and 'alternative Europe'. Stephen White and Valentina Feklyunina are sharply critical of the EU's identification of itself as 'Europe' and the attempt to impose its values and acquis on the region. Instead, they call for the acknowledgement of a plurality of 'Europes' and

${ }^{23}$ Aleksei A. Gromyko and V. P. Fëdorova eds, Bol'shaya Evropa: Idei, real'nost', perspektivy (Moscow: Ves' Mir, 2014).

${ }^{24}$ In his European parliamentary election speech in Nîmes on 5 May 2009, Sarkozy argued that Turkey 'is not intended to become an EU member', but in a notable innovation he placed Russia and Turkey on an equal footing, noting that both countries should establish 'an economic and security common area' with the EU. A new bloc would thus be created 'of 800 million people who share the same prosperity and security'. In this system 'Russia should not consider itself an adversary of Europe but a partner'. 'Déclaration de M Nicolas Sarkozy, Président de la République, sur l'action de la France en faveur de la construction européenne, à Nîmes le 5 Mai 2009', http://discours.vie-publique.fr/notices/097001329.html, accessed 7 April 2015. 
the search for accommodation (what I term a 'mode of reconciliation') between them that respects the diversity of traditions. ${ }^{25}$

This picture of competing visions of Europe $\{7\}$ forces some rethinking about a new interpretation of pan-Europeanism in the post-Cold War era. As Yeltsin put it: 'Europe without Russia is not Europe at all. Only with Russia can it be a greater Europe, with no possible equal anywhere on the globe. ${ }^{, 26}$ In other words, Russia could help Europe fulfil its potential. Equally, Russia's vast but relatively underdeveloped resources and developmental contradictions needed western Europe's advanced technologies and managerial capacity. The two complemented each other. To facilitate a positive interaction, an appropriate political form needed to be devised - but this was not found during the quarter-century of the cold peace. While the Russian leadership expended considerable effort on devising ideas for a new 'architecture' for a united Europe, the other countries saw no need for new ideas, since as far as they were concerned 'wider Europe' was a perfectly viable model, complemented not by Russia but by the United States.

As Russia's estrangement from the 'wider Europe' project intensified, it placed ever greater emphasis on plans for a greater Europe. The idea of a new European Security Treaty, announced by Medvedev in a speech in Berlin on 5 June 2008, called for the creation of a genuinely inclusive new security order, arguing that new ideas were required to ensure that dividing lines were not once again drawn across the continent. ${ }^{27}$ The initiative was greeted with polite condescension by the Atlantic powers, although the OSCE established the 'Corfu process' to assess the proposal. In a speech in Berlin on 26 November 2010 Putin called for the geopolitical unification of all of

\footnotetext{
${ }^{25}$ Stephen White and Valentina Feklyunina, Identities and foreign policies in Russia, Ukraine and Belarus: the other Europes (London: Palgrave Macmillan, 2014).

${ }^{26}$ Cited by Leonid Bershidsky, 'No illusions left, I'm leaving Russia', Moscow Times, 19 June 2014.

${ }^{27}$ Dmitry Medvedev, 'Speech at meeting with German political, parliamentary and civic leaders', Berlin, 5 June 2008, http://archive.kremlin.ru/eng/speeches/2008/06/05/2203_type82912type82914type84779_20215 3.shtml, accessed 5 April 2015.
} 
'greater Europe' from Lisbon to Vladivostok to create a genuine 'strategic partnership' ${ }^{28}$ Rather surprisingly, given the rapid advance of Eurasian integration, Putin returned to the idea of creating a free trade zone from the Atlantic to the Pacific at the Russia-EU summit in Brussels on 28 January 2014 (as it turned out, the last of the series). ${ }^{29}$ In his meeting with Russian ambassadors on 1 July 2014 Putin suggested that Europe's security problems could be resolved by creating a 'single economic and humanitarian space from Lisbon to Vladivostok' ${ }^{30}$ Putin's insistence that the Eurasian Economic Union (EEU) was not an alternative but a complement to European integration echoed Gorbachev's ideal of a united continent. Putin insisted that the plan was not to 'fence ourselves off from anyone', but to found an institution on 'universal integrative principles as an inalienable part of greater Europe, united by mutual values of freedom, democracy and market rules'.31

In the event, Russia's various initiatives in favour of the greater European agenda gained little traction in the West, typically being dismissed as being little more than a cover for the establishment of a 'greater Russia' by stealth, while 'greater European' ideas mostly remained vague and nebulous. The Atlantic community remains intensely vigilant against attempts to 'drive a wedge' between its two wings, but this has foreclosed the exploration of options that might have

${ }^{28}$ Speech delivered to the Fourth Berlin Economic Leadership meeting organized by the Süddeutsche Zeitung, which was presented as an article in the previous day's edition of the paper. A summary of the speech is at http://premier.gov.ru/events/news/13120/, accessed 5 April 2015; the article is Wladimir Putin, 'Von Lissabon bis Wladiwostok. Handelspakt zwischen Russland und Europa: Moskau will als Lehre aus der größten Krise der Weltwirtschaft seit acht Jahrzehnten wesentlich enger mit der Europäischen Union zusammenarbeiten', Süddeutsche Zeitung, 25 Nov. 2010.

${ }^{29}$ Vladimir Putin, 'Russia-EU summit', 28 Jan. 2014, http://eng.kremlin.ru/transcripts/6575, accessed 5 April 2015.

${ }^{30}$ Vladimir Putin, 'Soveshchanie poslov i postoyannykh predstavitelei Rossii', 1 July 2014, http://kremlin.ru/transcripts/46131, accessed 8 July 2014.

${ }^{31}$ Vladimir Putin, 'Novyi integratsionnyi proekt dlya Evrazii: budushchee, kotoroe rozhdaetsya segodnya', Izvestiya, 4 Oct, 2011, p. 1, http://premier.gov.ru/events/news/16622, accessed 5 April 2015. 
enhanced the security of all. The Cold War fear of dissolution is accompanied by the hermetic concern to guard against potentially divisive and dangerous ideas emanating from outside the Atlantic alliance. Nonetheless, Atlanticism is permanently challenged by one version or another of the greater European idea. Even the German Chancellor, Angela Merkel, referred to greater Europe at the 51st Munich Security Conference on 7 February 2015, insisting that there could be no military solution to the crisis in Ukraine and arguing that peace in Europe could only be secured with Russia rather than against it. ${ }^{32}$ The development of greater Europe remains a way of negotiating what in the best of circumstances is a complex and difficult relationship between Russia and the Atlantic community while ensuring space for the sovereign development of the lands in between.

\section{The EU, Russia and Atlanticism}

The failure to generate a mode of reconciliation between contrasting views of the world, including the Atlanticist and continental visions, meant that the EU's relations with Russia were problematic from the beginning, and became only more so with the passage of time. The two entities existed, as it were, in different temporal realities (the Krastev-Wilson argument); or, as those taking a more Marxist approach would argue, at very different stages of development. Sergei Prozorov has demonstrated that the relationship was built not on the basis of sovereign equality but on the tutelary principle of teacher and pupil. ${ }^{33}$ The practical expression of this was evident in the way that the EU's Common Strategy on Russia (CSR) of 1999 was devised: despite some early contacts with Russian officials, it 'was nevertheless very much a unilateral exercise'. There was not much that was 'common', 'in the sense that they are the result of mutual

\footnotetext{
32 'Statement and discussion with Dr Angela Merkel',
} https://www.securityconference.de/en/media-library/video/single/statement-and-discussion-withdr-angela-merkel/, accessed 5 April 2015. For analysis, see Ben Aris, 'Putin's vision: building a greater Europe by 2050', Business New Europe, 13 Feb. 2015, http://www.bne.eu/content/story/moscow-blog-putins-vision-building-greater-europe-2050, accessed 5 April 2015.

${ }^{33}$ Sergei Prozorov, Understanding conflict between Russia and the EU: the limits of integration (Basingstoke: Palgrave Macmillan, 2006). 
consultations between two partners'; instead, the 'common' referred to was the position of the member states. ${ }^{34}$ This applied equally to the Partnership and Cooperation Agreement (PCA), which was signed in 1994 but did not come into force until 17 December 1997, and also to the interim agreement on trade-related matters signed in 1995: 'Both proved to be inadequate bilateral instruments for the purposes of governing the relations between the two sides.' 35 Numerous commentators in Russia were receptive to the argument that an enlarged EU was the cornerstone of stability in Europe, but dissenting voices were raised from the start. For example, the former Soviet Ambassador to the European Community, Vladimir Shemyatenkov, argued that 'despite all the sweeteners of a partnership $\{\mathbf{8}\}$, it [EU enlargement] means the actual exclusion of Russia (and the Russians) from the zone of peace, stability and prosperity' ${ }^{36}$ Exclusion was certainly not a deliberate EU policy, and indeed extraordinary efforts were made to give substance to rhetorical claim of 'partnership', including the 'common spaces' programme of 2004 and the 'Partnership for Modernisation' announced in 2010. ${ }^{37}$ Nevertheless, to this day 'the legal framework for the relationship [between the EU and Russia] remains, in some sense, unresolved'. ${ }^{38}$ Equally, the EU failed to socialize the new east European member states into the normative foundations of the peace project, and instead some of the new members sought to use the EU to pursue longstanding grievances against Russia. Thus conflicts, rather than being transformed, were amplified. This applies in particular to the three Baltic states and Poland, who brought a range of historical grievances (notably the Katyn massacre of Polish officers and reservists in the case of Poland, and extensive ethnic Russian in-migration in the case of Estonia

\footnotetext{
${ }^{34}$ Marc Maresceau, 'EU enlargement and EU common strategies on Russia and Ukraine: an ambiguous yet unavoidable connection', in Christophe Hillion, ed., EU enlargement: a legal approach (Oxford and Portland, OR: Hart, 2004), p. 183.

${ }^{35}$ Maresceau, 'EU enlargement and EU common strategies on Russia and Ukraine', p. 184.

${ }^{36}$ Cited in Maresceau, 'EU enlargement and EU common strategies on Russia and Ukraine', $p$. 184 (emphasis in original)\{?\}.

${ }^{37}$ On the latter, see Maxine David and Tatiana Romanova, eds, Modernisation in EU-Russian relations: past, present and future, special issue of European Politics and Society 16: 1, 2015. ${ }^{38}$ Maxine David, 'EU-Russia relations: effects of the 2014 Ukraine crisis', Russian Analytical Digest, no. 158, Dec. 2014, p. 5.
} 
and Latvia) to the EU table.\{9\} This reinforced the exclusionary logic, which trumped partnership policies. The Eastern Partnership (EaP), formally launched in May 2009 on the basis of a joint Polish and Swedish initiative, from the first aroused concern in both Brussels and Moscow about its potential to generate conflict. ${ }^{39}$

This trend culminated in the systematic efforts to keep Russia out of negotiations of the Association Agreement (AA) with Ukraine. The ostensible argument was that the AA was a bilateral deal and had nothing to do with third parties, even though it would have a profound effect on bilateral economic and other relations between Russia and Ukraine. Even Andrew Wilson's panegyric to the Maidan revolution notes that when First Deputy Prime Minister Igor Shuvalov travelled to Brussels in February 2013 to try finally to start substantive negotiations, he came away empty-handed. ${ }^{40}$ In structural terms, this represented a failure of 'inter-regionalism' on a monumental scale. ${ }^{41}$ The effect of enlargement and association agreements on the neighbours of the enlarged EU has been inadequately problematized, as has the quality of the political relationship between the EU and its 'partner' countries in the borderlands of Europe, which has too often taken the form of 'power projection'. ${ }^{42}$ Instead of achieving a Europe 'free of new dividing lines', enlargement effectively created a renewed division of Europe while restoring classical imperial tropes of power relations between core and periphery. The realist

${ }^{39}$ Nathaniel Copsey and Karolina Pomorska , 'The influence of newer member states in the European Union: the case of Poland and the Eastern Partnership', Europe-Asia Studies 66: 3, 2014, pp. 421-43.

${ }^{40}$ Andrew Wilson, Ukraine crisis: what it means for the West (London and New Haven: Yale University Press, 2014), p. 17.

${ }^{41}$ Rilka Dragneva and Kataryna Wolczuk, 'The EU-Ukraine Association Agreement and the challenges of inter-regionalism', Review of Central and East European Law 39: 3-4, 2014, pp. $213-44$.

${ }^{42}$ Simone Tholens and Raffaella A. Del Sarto, 'Partnership or power projection? The EU and its “neighbourhood", OpenDemocracy, 18 Nov. 2014, https://www.opendemocracy.net/caneurope-make-it/simone-tholens-raffaella-adel-sarto/partnership-or-power-projection-eu-and-its'n, accessed 5 April 2015. 
critique of the EU is certainly far from new, ${ }^{43}$ but the Ukraine crisis represented a challenge to the EU's survival as a transformative institution with the potential to mitigate the logic of conflict on the continent. Early critics of the EU had condemned it as little more than an instrument in the Cold War, and their arguments were now restored to the overflowing quiver of critiques of the EU.

Normative rhetoric accompanied by realist practices reinforced an issue that is obscured by the categorization of the EU as 'post-modern' and post-Westphalian, namely the increasing convergence between the EU and NATO. The emergence of a revived Atlanticism is one of the salient characteristics of Europe in the wake of the Ukrainian crisis, although of course there remain tensions between the US and the EU, not least over Ukraine, as well as between EU member states. The new Atlanticism is certainly far from being a complete and monolithic project, but it is the framework within which the 'Euro-West' engages with security matters. The very multiplicity of layers makes engagement with outside players complex and confusing. In the environment of an increasingly divided continent, this generated numerous security dilemmas focusing on Russia. American security initiatives, notably plans to install elements of ballistic missile defence (BMD) in eastern Europe, the apparently unstoppable dynamic of NATO enlargement, and the development of the EU's Common Security and Defence Policy (CSDP) are all facets of the security dilemmas exacerbated by the new Atlanticism. While the EU in its aspirations is undoubtedly in liberal terms a benign and progressive phenomenon, it is only one half of the Atlantic walnut. The other part is NATO, while overarching the two is American 'leadership'. Thus the EU may well be post-territorial, but the announcement in April 2007 that America planned to build a BMD system in central Europe was a harsh reminder that Europe remained firmly part of a spatialized and militarized world order.

This raises some fundamental questions about the agency of the EU within the framework of a complex Euro-Atlantic security system that is becoming a more ramified economic and civilizational community in its own right. The EU's commitment to a bundle of normative public goods, including good governance, the rule of law, defensible property rights and genuinely

${ }^{43}$ See e.g. Adrian Hyde-Price, "Normative” power Europe: a realist critique', Journal of European Public Policy 13: 2, 2006, pp. 217-34; Michelle Pace, 'The construction of EU normative power', Journal of Common Market Studies 45: 5, 2007, pp. 1041-64. 
competitive markets and elections is in danger of being vitiated by the manner of their implementation. The 'new' eastern Europe (NEE), encompassing the three states now directly between Russia and the EU, namely Belarus, Moldova and Ukraine, along with the three republics in the South Caucasus, Armenia, Azerbaijan and Georgia, became the source of contention. The contradiction lies in the fact that the good governance norms promulgated by the EU\{10\}, while pre-eminently technocratic, have become politicized while lacking an overarching normative commitment to the idea of a plural and united Europe. Instead, the commitment is increasingly to the new Atlanticism. The absence of a continental vision means that when these norms encountered a resistant other, in this case Russia, the norms themselves became geopolitical, even if their intent was benign and transformative. This is the essence of the structural argument about the breakdown in relations between Russia and the Atlantic community.

Democracy assistance and all the other aspects of partnership between Russia and Atlantic institutions lacked a strategic common purpose, such as the commitment to create a 'new Europe' from ocean to ocean, and instead Russia was asked to reinforce structures that served to undermine its identity as a sovereign and equal partner in a common endeavour. Resistance to Russia's perceived self-immolation in structures not of its making had already begun in the 1990s under Yeltsin, although there was as yet no sustained argument about a structural incompatibility of purpose. Under Putin, resistance became increasingly assertive. ${ }^{44}$ The 'transdemocratic' claim by the EU and NATO that security can be advanced by promoting liberal democracy and integration into European institutions became a fundamental issue of contention when perceived to take the form of aspirations for 'regime change' through the practices of colour revolutions. At the heart of the idea of transdemocracy in the European context is the coupling of democracy and human rights with the expansion of the Atlantic community. The ideology of transdemocracy assumes that if democracy is the best possible form of government and the one that is liable to make allies of the states that adopt it [democracy]

\footnotetext{
${ }^{44}$ Stephen F. Cohen, 'Who lost the post-Soviet peace?', in Soviet fates and lost alternatives: from Stalinism to the new Cold War (New York: Columbia University Press, 2009), pp. 162-98.
} 
$\{\mathbf{1 1}\}$, then all practicable measures should be employed to achieve the desired end. ${ }^{45}$ The main instrument for this 'systemic' approach to the conduct of international politics came to be seen as 'colour' revolutions, mass popular mobilizations against attempts to 'steal' elections, whose classic exemplar was the events in Ukraine of autumn 2004. The emphasis on democracy promotion in George W. Bush's intervention in Iraq and western support for the civil associations active in the 'colour revolutions' in Georgia, Kyrgyzstan and Ukraine, in Thomas Carothers' words, 'triggered heightened sensitivities about democracy aid in various places, especially Russia and other post-Soviet countries'. Carothers goes on to note that 'even as the color revolutions faded and a new U.S. president [Barack Obama] took a far less assertive stance on democracy promotion, the backlash kept growing'. ${ }^{46}$

From the perspective of an increasingly confident Russia, the transdemocratic challenge was perceived to be a threat of the first order not only to its conception of international politics, but above all to the stability of domestic regimes, especially when the ideology of transdemocracy was backed up by an extensive network of civil society associations sponsored by the United States and European countries. The perception that the West was using democracy promotion as a cover to advance its strategic objectives, including regime change, aroused a host of defensive reactions. ${ }^{47}$ The transdemocratic interpenetration of the ideology of democracy and the mailed fist of the Atlantic security system was, not surprisingly, perceived as a threat to those on the receiving end. These fears were exacerbated by the 'anti-imperial' rhetoric of some of the new post-communist members of NATO and the EU, and the Russophobic rhetoric of the nationalizing elites in Georgia and Ukraine. These fears were inevitably fanned by nationalistic radicals of various stripes in Russian public discourse. ${ }^{48}$ For Russia and other countries, the gripe

45 The related concept of 'inter-democracy' is explored by Glenn Diesen, EU and NATO relations with Russia: after the collapse of the Soviet Union (Aldershot: Ashgate, 2015). 46 Thomas Carothers, 'Democracy aid at 25: time to choose', Journal of Democracy 26: 1, 2015, p. 68.

${ }^{47}$ Robert Horvath, Putin's 'preventative counter-revolution': post-Soviet authoritarianism and the spectre of velvet revolution (London and New York: Routledge, 2013).

${ }^{48}$ For example, the neo-Eurasianist Alexander Dugin reprises the argument of the original Eurasianists that Russia is not and cannot be part of Europe and that the relationship between 
is not so much with democracy as a practice but its advancement as a project. This is perceived to be aggressive, expansionist and ultimately subversive of state sovereignty. Certainly, the critique of transdemocracy can be used as a cover for authoritarianism, but the official Russian view argues that it is also an appeal for a diverse international order which recognizes alternative types of systemic development and ideational pluralism. Resistance to transdemocracy does not necessarily in the long term have to be anti-democratic, while recourse to the language of 'civilizational' choice is redolent of the worst forms of orientalism.

The asymmetrical end of the Cold War, in which the transdemocratic powers asserted victory while Russia, unlike Germany or Japan at the end of the Second World War, refused to 'embrace defeat', generated a cycle of conflict that is far from over. ${ }^{49}$ An extended period of 'cold peace' settled over relations between Russia and the West, although punctuated by attempts by both sides to escape the logic of renewed confrontation. This is what I call a mimetic Cold War: one that reproduced the practices of the Cold War without openly accepting the underlying competitive rationale. ${ }^{50}$ This is a post-ideological Cold War, since the clash is between variants of capitalist modernity, intended to achieve 'a concert of capitalist powers [that] could manage competition among integrated but diverse models of political economy'. This would be a 'pluralist order' in which there would be 'respect for, or at least tolerance of, difference, and a willingness to adapt to the realities of power'. ${ }^{51}$ Instead, increasingly monist representations prevailed on both sides, generating a competitive dynamic in European international relations. Tensions were fuelled by nationalist elites in some post-communist countries, supported by neo-

Russia and Europe is inherently conflictual. For his recent thinking on how he would like to see the Putin model, see Aleksandr Dugin, Novaya formula Putina: Osnovy eticheskoi politiki (Moscow: Algoritm, 2014). The influence of such thinking on Putin tends to be greatly exaggerated, and is not reflected in official foreign and security policy documents.

${ }^{49}$ John W. Dower, Embracing defeat: Japan in the wake of World War II (New York: Norton, 2000).

${ }^{50}$ Richard Sakwa, 'The cold peace: Russo-Western relations as a mimetic Cold War', Cambridge Review of International Affairs 26: 1, 2013, pp. 203-24.

${ }^{51}$ Barry Buzan and George Lawson, 'Capitalism and the emergent world order', International Affairs 90: 1, Jan. 2014, p. 90. 
conservatives and liberal interventionists in Washington, who fed concerns about Russia's alleged inherent predisposition towards despotism and imperialism. ${ }^{52}\{\mathbf{1 2}\}$ This became a selffulfilling prophecy: Russia, treated as the enemy, in the end became one. NATO, embedded in an increasingly ramified Atlanticist nexus, thus found a new role, which was remarkably similar to what it had been set up to do in the first place - to 'contain' Russia.

The structural logic of conflict could theoretically have been avoided by deepening the structures and practices of liberal internationalism within the framework of a shared continental vision. John Ikenberry correctly notes that 'China and Russia . . . are not full-scale revisionist powers but parttime spoilers at best, as suspicious of each other as they are of the outside world'. ${ }^{3}$ In the event, deepening economic relations and the dense structure of the networks of global and regional governance did not temper the potential for conflict, as anticipated by the classic postulates of interdependency theory. ${ }^{54}$ Above all, although the EU is based precisely on extending the arc of good governance and rule-based economic relations, these principles increasingly became enmeshed in competition with Russia. The EU's normative concerns were in the end trumped by the transdemocratic geopolitical aspirations of the new Atlanticism to extend its zone of influence to the east. The two sets of purposes became conflated and thus confused. The EU ultimately came

52 One of the eastern European leaders most hostile to Russia is President Dalia Grybauskaite of Lithuania, who in October 2014 called Russia a 'terrorist state', eliciting the warning from the Russian foreign ministry that she would be advised to temper her 'komsomol fervor, a possible reference to her work teaching 'the political economy of socialism' for the Vilnius Higher Party School in the 1980s. Mikhail Klikushin, 'President of Lithuania gets punk'd after declaring Russia a "terrorist state"', The Observer, 14 December 2014, available at http://observer.com/2014/12/president-of-lithuania-getspunkd-after-declaring-russia-a-terrorist-state/, accessed 7 April 2015. The memoirs of Hillary Clinton as Secretary of State are replete with disparaging comments about Russia. She provides a good example of the circularity of the argument - that after the Cold War, 'the [NATO] alliance prepared for new threats to the security of the transatlantic community', which the enlargement of that community itself provoked. As she notes, 'Virtually all of the former Soviet republics, other than Russia itself, felt vulnerable without some security guarantees from the West, given their fear that Russia might someday revert to aggressive, expansionist behavior'. Hillary Rodham Clinton, Hard Choices: a Memoir (New York: Simon \& Schuster, 2014), p. 211.

${ }^{53}$ John Ikenberry, 'The illusion of geopolitics: the enduring power of the liberal order', Foreign

Affairs 93: 3, 2014, p. 80.

${ }^{54}$ Robert O. Keohane and Joseph Nye Jr., Power and interdependence, 2nd edn (New York, HarperCollins, 1989); for a later examination of the issue, see Robert O. Keohane, 'From interdependence and institutions to globalisation and governance', in Robert O. Keohane, ed., Power and governance in a partially globalised world (New York, Routledge, 2002), pp. 1-23. 
into conflict with Russia in a fight over what has now become not the shared but the contested neighbourhood of the new eastern Europe. This is not to suggest that the EU should have given up on extending its reach to the NEE; however, classic diplomatic mechanisms of accommodation and bargaining could have tempered the conflict potential. A clearer articulation of the distinction between the European and Atlanticist projects would have helped. Instead, the European Commission, especially under the leadership of José Manuel Barroso, became the epitome of hermetic insensitivity. Well before the Ukraine crisis, relations between Moscow and the Commission had run into a dead end, as evidenced by the failure to establish even a minimal consensus over the successor to the PCA after the initially agreed decade ran out in 2007. The realist approach to politics, which focuses on interests and issues of national security, would have alerted policy-makers to the dangers of advancing into a region replete with its own norms and traditions and engaging in an integrative project of its own. ${ }^{55}$ As John Mearsheimer forcefully reminds us, most realists were opposed to NATO expansion, and he recalls George Kennan's strictures on the folly of enlargement. ${ }^{56}$ Equally, Henry Kissinger stresses that the vitality of an international order depends on the balance it strikes between legitimacy and power: both are subject to evolution and change, but 'when that balance is destroyed, restraints disappear, and the field is open to the most expansive claims and most implacable actors; chaos follows until a new system of order is established'. 57 The Versailles settlement, in his view, placed excessive emphasis on the legitimacy component and appeals to shared principles, and by ignoring the element of power all but dared Germany to embark on revisionism. ${ }^{58}$ This is a nice description of the present European disorder.

${ }^{55}$ On the latter, see Rilka Dragneva and Kataryna Wolczuk, eds, Eurasian economic integration: law, policy and politics (Cheltenham: Edward Elgar, 2013); Piotr Dutkiewicz and Richard Sakwa, eds, Eurasian integration: the view from within (London and New York: Routledge, 2015).

56 John J. Mearsheimer, 'Why the Ukraine crisis is the West's fault: the liberal delusions that provoked Putin', Foreign Affairs 93: 5, 2014, pp. 77-89.

${ }^{57}$ Henry Kissinger, World order: reflections on the character of nations and the course of history (London: Allen Lane, 2014), p. 66.

${ }^{58}$ Kissinger, World order, p. 83. 


\section{The new Atlanticism}

A vacuum has opened up where the idea of European unity once stood. On the one side, Russia is engaged in its own integrative projects, primarily the Eurasian Economic Union launched on 1 January 2015, and is turning towards closer ties with Asian powers, notably China. On the other side, the Atlantic security community is evolving into a far broader alliance system combining security with more intense political and economic ties. The new Atlanticism is evolving into a political force that is overcoming the loss of direction and purpose of the early post-Cold War years. Having lost its original rationale with the end of the Cold War, the Atlantic community cast around for a new purpose, which it initially found by going 'out of area' to stop it going 'out of business'. The two and a half decades after the end of the Cold War can now be seen as little more than a hiatus in which NATO fought wars in south-east Europe and Afghanistan, but above all sought to achieve the impossible: to retain its original Atlantic character by ensuring a continuing American commitment to European security, while bringing Russia in as a security partner. The efforts devoted to the latter goal were both genuine and intense, but in the end were vitiated by the various enlargements that brought the alliance to Russia's borders, the imposition of a missile defence system on European territory, ideational debates about sovereignty and autonomy, and the pronounced anti-Russian stance of some of the new members. In the end the Atlantic community found its new purpose by returning to a reformulated version of its original goal-keeping Russia out. Although challenged by problems of internal coherence, diverging ambitions, competing representations of NATO's ultimate purpose and mission, reluctance to meet defence spending commitments and political resistance to the new division of Europe, the new Atlanticism is becoming the framework within which these issues are being discussed. The ease with which the NATO alliance slipped back into a posture of Cold War confrontation with Russia illustrates the increasingly hermetic and comprehensive character of the organization. By hermetic I mean that while the security system created in the wake of the Second World War II enlarged considerably after 1989, above all to encompass a great swathe of former communist Soviet bloc states and even a part of the former Soviet Union (the Baltic states), its internal rationale and structures remained remarkably impervious to change despite the collapse of the Iron Curtain and Russia's uncertain path towards capitalist democracy and international integration. Russia did not become a fully fledged member of the new security community, generating tensions and potential contestations that exploded over Ukraine in 2014. 
The Atlantic alliance had always been a distinctly normative enterprise, as formulated in the Atlantic Charter of 14 August 1941, but when this basis was combined with the transdemocratic agenda it assumed an increasingly inflexible ideological character. The Ukraine crisis demonstrated a new rigidity in policy and selectivity in understanding complex information flows. Above all, the fundamental tension in postwar European development, namely the relationship between the European and American wings of the alliance, remains unresolved. This is not to argue that separation is appropriate, but to suggest that a debate on the way in which Atlanticism can be rendered compatible with a mode of reconciliation at the pan-European level would be appropriate. Various ideas have been mooted about how this could be achieved, including some sort of Helsinki 2 conference. The new Atlanticists naturally dismiss such ideas and have instead advocated ramping up the pressure on Russia through sanctions and other measures on Russia. This assumes that applying a linear 'deterrence model' to Russia will achieve the desired outcome, whereas, as Stephen Walt argues (drawing on the classic 'security dilemma' idea of Robert Jervis ${ }^{59}$ ), a the bundle of insecurities that define Russian actions is more accurately defined by a 'spiral model'. ${ }^{60}$ A very different approach was taken by Donald Tusk, the former Polish prime minister who took over as President of the European Council in December 2014. Tusk argued that 'Europe must maintain broad economic sanctions against Russia until Ukraine has regained control of its border or risk a crisis with the White House,' accusing some EU leaders of 'appeasement' of Russia and of 'preferring "naivety or hypocrisy" in seeking to give Vladimir Putin the benefit of the doubt'. He called for the full implementation of the Minsk 2 agreement of 12 February 2015, including Ukrainian control of its border with Russia, before sanctions were eased, but failed to mention that border controls were to be restored only after a constitutional process that granted the rebellious regions some sort of agreed

\footnotetext{
${ }^{59}$ Robert Jervis, Perception and misperception in international politics (Princeton, NJ: Princeton University Press, 1976).

${ }^{60}$ Stephen M. Walt, 'Why arming Kiev is a really, really bad idea', Foreign Policy, 9 Feb. 2015, http://foreignpolicy.com/author/stephen-m-walt/, accessed 5 April 2015.
} 
autonomy. ${ }^{61}$ This sort of Atlanticism served only to confirm the death of Europe as the subject of its fate.

There was little scope here for any kind of pan-European process to restructure the European security system, whose breakdown was so vividly in evidence in the struggle over Ukraine. Russian advocacy of some sort of greater European security system and model of continental unification can be interpreted as hostile to existing patterns of transatlantic relations and the EU's model of systemic political transformation of its neighbourhood, but this is precisely the greatest challenge. The creation of some sort of greater European structure would potentially foster a more benign geopolitical environment in which Russia's own systemic transformation could take place. Although sponsored by Russia today, the greater European project does not belong to Russia but is part of the broader European patrimony. The greater European idea offers the potential for precisely the missing mode of reconciliation alluded to earlier. However, its transformative potential will only be realized if greater Europe become a project for the whole continent.

As for the new Atlanticism's comprehensive character, this is something that has been gaining in intensity in recent years as the foreign and security dimension of the EU has effectively merged with the Atlantic security community. Since the Treaty of Lisbon (the 'Reform Treaty') of 13 December 2007, which came into effect in 2009, the Common Foreign and Security Policy (CFSP) is now in substance part of an Atlantic system. Accession countries are now required to align their defence and security policies with those of NATO, resulting in the effective 'militarization' of the EU. Several articles in the Association Agreement between the EU and Ukraine that was to have been signed at the Vilnius summit of the Eastern Partnership on 28-9 November 2013 covered security issues, which together would irrevocably draw Ukraine into the Atlantic security orbit. Article 4 speaks of the 'Aims of political dialogue', with section 1 stressing that: 'Political dialogue on all areas of mutual interest shall be further developed and strengthened between the Parties. This will promote gradual convergence on foreign and security matters with the aim of Ukraine's ever deeper involvement into the European security area.' Article 7.1 called for EU-Ukrainian convergence in foreign affairs, security and defence.

${ }^{61}$ Ian Traynor, 'Why Europe must not compromise with Kremlin on Ukraine, by man at EU's helm', Guardian, 16 March 2015, p. 19. 
As if this were not explicit enough, article 10 on 'conflict prevention, crisis management and military-technological cooperation' noted in section 3 that: 'The parties shall explore the potential of military and technological cooperation. Ukraine and the European Defence Agency (EDA) will establish close contacts to discuss military capability improvement, including technological issues.' This would not have been a problem if some overarching and mutually satisfactory security agreement between Russia and the Atlantic system — what I refer to as a potential 'mode of reconciliation' - had been in place; but, as we have seen, relations between the two sides had long been deteriorating. Even the traditional neutrality of some of the countries is being questioned, with Atlanticists in both Sweden and Finland exploiting the Ukraine crisis to shift their countries closer to NATO. Although security policy-making in the EU even after Lisbon remains consensus-based and intergovernmental, the European External Action Service (EEAS) sought to generate greater coherence in supporting the work of the High Representative of the Union for Foreign Affairs and Security Policy. ${ }^{62}$ In the Ukraine crisis the inaugural holder of this post, Catherine Ashton, failed to provide a distinctive voice that could mediate between Washington and Moscow or reconcile the various concerns of the member states. The agency of the EU in this crisis was found wanting.

The new Atlanticism has been long in the making and represents the internal transformation of the traditional security system into a new type of community. In keeping with its hermetic and comprehensive character, the new Atlanticism has effectively made security an exclusive public good. If in the past security emerged out of a balance of power or some sort of arrangement where different states engage in diplomacy to manage difference (on the lines of the nineteenthcentury Concert of Powers), the new power system guarantees security for its own members and allies (although of course to a different degree for the latter), but increasingly lacks a mechanism to engage in genuine equilateral security relations with others. This dangerously one-sided stance, reinforced by the practices of transdemocracy, replicates the structural exclusion mechanism that we noted in EU relations with Russia. All NATO secretaries general in the postCold War era have made sustained efforts to mitigate this mechanism, but all have clearly failed to achieve the creation of an inclusive security structure for Europe. There was no way to

${ }^{62}$ Rosa Balfour, Caterina Carta and Kristi Raik, eds, The European External Action Service and national foreign ministries (Farnham: Ashgate, 2015). 
reconcile the concerns of other states with geopolitical interests that do not coincide with those of the Atlantic community; and instead, in the absence of a mode of reconciliation, the logic of confrontation steadily increased.

\section{Russian neo-revisionism}

The dominant narrative of the new Atlanticism is that Russia has become a revisionist power and is solely responsible for the breakdown of the European security order. This is a dangerous simplification of the complex structural factors that precipitated the confrontation between Russia and the Atlantic system, and is likely to lead to mistaken policy responses. Unlike interwar Germany, contemporary Russia is not a revisionist power, although it does challenge the balance between power and legitimacy instantiated in the post-Cold War European settlement. This challenge forced Russia to become what I call a neo-revisionist power, questioning neither the basic territorial arrangements of Europe nor even the basic normative premises on which contemporary world order is based, but demanding a recognition of Russia's claim to be an equal in that power system and thus a legitimate partner in the stewardship of world affairs. America's claim to be the 'indispensable power' is thus questioned, as is the EU's claim to normative tutelage. However, Russia's initial motivation in both the Georgian and Ukrainian conflicts was pre-eminently defensive. Thus the Ukraine crisis, as Andrei Tsygankov argues, represented 'Putin's last stand' in his struggle for recognition of Russia's interests and values. He dismisses alternative explanations of Russia’s behaviour that stress Russian imperialism, the regime's 'diversionary politics' aimed at distracting attention from domestic problems, divergent national identities or Putin's ressentiment. ${ }^{63}$

In the 1990s there was not much that Russia could do about the asymmetrical end of the Cold War, since it was economically weak and locked into an extended 'transition' period as it became something approximating a market economy. Putin's accession to the presidency in 2000 coincided with the beginning of an extended period of high prices for raw materials, above all for oil and gas. Russia enjoyed annual GDP\{13\} growth of 8 per cent up to the onset of the great

\footnotetext{
63 Andrei P. Tsygankov, 'Vladimir Putin's last stand: the sources of Russia's Ukraine policy', Post-Soviet Affairs, published online 4 Feb. 2015, http://www.tandfonline.com/doi/abs/10.1080/1060586X.2015.1005903\#.VNTerGjF9Qs, accessed 5 April 2015.
} 
recession from 2008. The Russian state greatly increased its extractive capacities, with tax revenues rising on the back of the defeat of the oligarchic model of capitalism in the early 2000s, notably through the 'Yukos affair' from 2003, which saw the Yukos oil company effectively expropriated and transferred into the hands of state-owned Rosneft, while its head, Mikhail Khodorkovsky, spent a decade in jail. ${ }^{64}$ Putin himself stepped down in 2008 after the two terms allowed him by the constitution, and for four years the country was governed by the relatively liberal Dmitry Medvedev. The latter promised to revive the country's democratic institutions, which had been increasingly suffocated by the system of 'managed democracy'. Medvedev achieved only modest success, but he established an agenda for the reform of the Putinite system that remains active to this day. ${ }^{65}$ When it comes to foreign affairs, according to Dmitri Trenin, Medvedev was sent by Putin on 'a sort of scouting mission to the West to determine what was possible to achieve with the United States and Europe. As Putin looked at the balance sheet three and a half years later, the results were not promising.' Putin concluded that 'the West's approach to Russia offered scant respect for its interests or views'. ${ }^{66}$ Trenin was already warning a decade ago that 'Russia has a choice between accepting subservience and reasserting its status as great power' ${ }^{67}$ A thousand years of Russian history determined what that choice would be. In the end it was perceived foreign policy threats, notably the western intervention in Libya in 2011, that ensured Putin's return to the presidency in 2012. In the UN Security Council vote on 17 March 2011 establishing a no-fly zone Russia abstained, allowing the western powers to overthrow Muammar Gaddafi by October. This was yet another instance of the 'regime change' that alarmed Russia so much, and that already had provoked an internal 'tightening of the screws' in the mid-2000s. By the time Putin returned to the presidency in May 2012 Russia was

\footnotetext{
${ }^{64}$ Richard Sakwa, Putin and the oligarch: the Khodorkovsky-Yukos affair (London: I. B. Tauris, 2014).

${ }^{65}$ Richard Sakwa, Putin redux: power and contradiction in contemporary Russia (London and New York: Routledge, 2014).

${ }^{66}$ Dmitri Trenin, 'Russia's breakout from the post-Cold War system: the drivers of Putin's course', Carnegie Moscow Center, 22 Dec. 2014, http://carnegie.ru/2014/12/22/russia-sbreakout-from-post-cold-war-system-drivers-of-putin-s-course/hxsm, accessed 5 April 2015. ${ }^{67}$ Dmitri Trenin, 'Russia leaves the West', Foreign Affairs 87: 4, July-Aug. 2006, p. 88.
} 
much stronger, and ready to assert itself in world politics. As noted above, in the wake of the problems exposed by the Five-Day War in 2008 the Russian armed forces became the object of a grand programme of reform and re-equipping. Russia under Putin presented itself not so much as anti-western but as the continuation of the 'genuine' West (pace Danilevsky, who argued in the Slavophile manner that the Slav cultural-historical type was fundamentally incompatible with the Franco-German historical type prevalent in Europe $\left.{ }^{68}\{\mathbf{1 4}\}\right)$ by other means: one committed to conservative values, traditional representations of state sovereignty and a multipolar international system - the code for the refusal to accept the hegemony of the Atlantic system. ${ }^{69}$ However, unlike the Slavophiles and their increasingly numerous latter-day adherents in contemporary Russia, Putin remains a 'European', but one cleaving to a vision of 'true' Europe, as opposed to the 'false' one being purused in the West. ${ }^{70}$ As Alexey Gromyko, the Director of the Russian Academy of Sciences Institute of Europe, puts it:

<ext> To be a Russian European does not mean to pursue exclusively a pro-Euroatlantic path; or a policy of integration into organizations which had been set up. At the same time the foreign policy of Russia is permeated with the understanding that the most developed and densely populated part of the country is located in Europe; that the last five centuries Russia's political and economic history has been massively linked to this part of the world. ${ }^{71}<$ extend> Russia was far from becoming a fully revisionist power since it asserted precisely the defence of the UN system and international law that it claimed that the West in its practices subverted, as well as defending its European identity. This is a type of 'neo-revisionism' that seeks not to challenge the fundamentals of international order but to ensure that Russia and other 'rising'

68 Nikolai Danilevskii, Rossiya i Evropa: Vzglyad" na kul'turnyya i politicheskiya otnosheniya Slavyanskago mira k" Germano-Romanskomu (Moscow: Kniga, 1991; with the title page a facsimile of the St Petersburg: Obshchestvennaya pol'za, 1871 edition),

${ }^{69}$ See Putin's first genuinely 'ideological' speech delivered to the Valdai Club, presenting Russia as the keeper of a western tradition that he argued the West itself had lost: Vladimir Putin,

'Meeting of the Valdai International Discussion Club', 19 Sept. 2013, http://eng.news.kremlin.ru/news/6007, accessed 5 April 2015.

${ }^{70}$ For the tension between the 'true' and 'false' Europes, see Iver B. Neumann, Russia and the Idea of Europe (London, Routledge, 1996).

${ }^{71}$ Alexey Gromyko, 'Smaller or greater Europe?', Revista di Studi Politici Internazionali 81:

324, Oct.-Dec. 2014, p. 517. 
powers are treated as equals in that system. ${ }^{72}$ Of course, this is a deeply problematic stance, but it is one that is shared in various degrees by Russia's partners in the BRICS grouping and others who are reviving a version of the 1970s idea of a New International Economic Order (NIEO). The veteran American diplomat and scholar Chester Crocker is right to point to the larger context: 'The Ukraine crisis did not emerge out of thin air. Its roots go back to the failures of Western-Russian diplomacy that left a large hole in the European order, to the venal elite networks ruling Kyiv and to the failure of a genuine democratic transformation in Russia itself. ${ }^{73}$ Russia undoubtedly 'broke the rules' in 2014 when it incorporated Crimea. ${ }^{74}$ These were the rules that Moscow claims were repeatedly breached by the West, as Putin claimed in his spirited defence of Russian actions over Crimea on 18 March 2014: 'They say that we are violating norms of international law. First, it's a good thing that they at least remember that there exists such a thing as international law-better late than never. ${ }^{75}$ It was the West, in his view, that had become revisionist, flouting international law whenever it suited its purposes, as in the invasion of Iraq in 2003, which Putin, together with France and Germany, vigorously opposed. However, contrary to much commentary, this did not signal the emergence of full-scale revisionism. That would have entailed the substantive repudiation of the operative structure of international law and the existing territorial arrangements. Instead, Putin spent most of his leadership trying to consolidate the existing borders and state system. A series of treaties with neighbours stabilized the existing borders, reflecting the deep conservatism of the Putin system. This is why the unilateral declaration of independence by Kosovo in February 2008, and its swift recognition by a number of leading Atlantic powers, represented such an affront to his way of

${ }^{72}$ Cf. Hiski Haukkala, 'A norm-maker or a norm-taker? The changing normative parameters of Russia's place in Europe', in Ted Hopf, ed., Russia's European choice (Basingstoke: Palgrave Macmillan, 2008), pp. 35-56.

${ }^{73}$ Chester A. Crocker, 'The strategic dilemma of a world adrift', Survival 57: 1, Feb.-March 2015, p. 20.

${ }^{74}$ Roy Allison, "Russian "deniable” intervention in Ukraine: how and why Russia broke the rules', International Affairs 90: 6, Nov. 2014, pp. 1255-97.

75 'Address by President of the Russian Federation', 18 March 2014, http:/eng.kremlin.ru/news/6889, accessed 5 April 2015. 
thinking. Each case is indeed different, but Russia's actions in Crimea were in part justified by the earlier precedent. ${ }^{76}$ The re-acquisition of Crimea was a response to what was perceived to be a substantive security threat —above all, the loss of access to the Sevastopol naval base. As the former British Ambassador to Russia, Tony Brenton, puts it: 'The seizure of Crimea and support for insurgency in east Ukraine were illegal and destabilising, but they were a response to a unique set of historical and political circumstances. ${ }^{, 77}$ All of this represents a neo-revisionist response to what were perceived to be threats, and to that degree represented a refusal to accept the status of a subaltern; but it does not represent a repudiation of the existing system of international relations or a sustained attempt to regain territory.

Russia is no longer the acquiescent partner of the early post-Cold War years. The experience of over two decades of traumatic domestic and international turmoil rendered both the Russian elite and Russian society ready to challenge western hegemony. This mood runs far deeper than the alleged effects of 'Putinite propaganda' in the mass media. ${ }^{78}$ Although Putin is held personally responsible for the breakdown in relations with the West, his views in fact reflect the deeper changes in Russian society over the past two decades. Igor Bunin and Aleksei Makarkin describe four long-term trends in Russia that underline the increasing alienation between Russia and the West: the strong sense of national self-sufficiency, complemented by a commitment to the country's Great Power status and leading role in the world; a strong sense of historical continuity, despite the numerous ruptures, based on statism and a sense of social justice; a deeply ingrained fear of loss of territory, perceived as a type of spiritual catastrophe; and finally, an emphasis on conspirological readings of public affairs. The idealization of the West characteristic of the perestroika and early post-communist periods is unlikely to return soon.

\footnotetext{
${ }^{76}$ For a thoughtful analysis, see Luca J. Uberti, 'Crimea and Kosovo: the delusions of western military interventionism', OpenDemocracy, 24 March 2014, https://www.opendemocracy.net/luca-j-uberti/crimea-and-kosovo-delusions-of-western-militaryinterventionism-nato-putin-annexation-legal, accessed 5 April 2015.

${ }^{77}$ Tony Brenton, 'Is no one in the West trying to do a deal with Putin?', Independent, 4 Jan. 2015.

${ }^{78}$ Ellen Mickiewicz, No illusions: the voices of Russia's future leaders (New York: Oxford University Press, 2014).
} 
Putin's attempts to establish a new relationship with the West based on equality represented a unique window of opportunity, but this has now been lost. Putin's view that the West is no longer a viable partner is shared by the population. ${ }^{79}$ This suggests the onset of a sustained period of confrontation, but it is one that was entirely avoidable.

\section{The strange death of Europe}

The Ukraine crisis exposed the flaws in Europe's post-Cold War development. The many dimensions of the EU's internal crisis have been discussed elsewhere, ${ }^{80}$ accompanied by a growing consensus that while the EU in its traditional form may be doomed, some form of 'deeper Europe' will thrive. ${ }^{81}$ In the Ukraine crisis the EU not only proved inadequate as a conflict regulator but itself became the source of conflict. The EU's ill-prepared advance into what was always recognized to be a contested neighbourhood provoked the gravest international crisis of our era, but once the crisis started Europe was sidelined. The drift towards merger with the Atlantic security system left the EU bereft of actor autonomy and policy instruments when it really mattered - when the issue was maintaining peace on the European continent. The Russian Foreign Minister, Sergei Lavrov, repeatedly expressed surprise at how little autonomy Europe really enjoyed when it came to the big decisions about the fate of the continent. He recalled the statement by US Vice-President Joe Biden that the American leadership had had to cajole Europe into imposing sanctions on Russia, even though the EU had initially been opposed to such

\footnotetext{
${ }^{79}$ Igor Bunin and Aleksei Makarkin, 'Rossiya vs. zapad: sotsial'no-politicheskie osnovaniya konflikta', Centre for Political Technologies, Dec. 2014, http://www.politcom.ru/18362.html, accessed 5 April 2015.

${ }^{80}$ For a wide-ranging analysis, see the Randall Hansen, ed., Europe 's crisis: background, dimensions, solutions, special issue of West European Politics, 37: 6, 2014.

81 The argument is advanced by Jan Zielonka (although he does not use the term 'deeper Europe') in Is the EU doomed? (Cambridge: Polity, 2014). For an erudite study of contemporary problems of European integration, see Nathaniel Copsey, Rethinking the European Union (Basingstoke: Palgrave Macmillan, 2015).
} 
measures. ${ }^{82}$ Lavrov noted 'that we for some previous years overestimated the independence of the European Union and even big European countries. So, it's geopolitics. ${ }^{83}$ At the same time, he called for the 'integration of integrations' between the EU and the EEU to create the foundations of the greater Europe. ${ }^{84}$

From a realist perspective, of course, there is no reason for the United States and its allies to accord Russia the status that it demands. Angela Stent's study of Russo-American relations in the post-Cold War period examines precisely how the mismatch in perceptions played out in practice, with Russia determined to ignore the enormous asymmetry in power and status, and America trying to find ways to deal with its assertive partner while ensuring its own freedom of action. ${ }^{85}$ However, the fundamental normative claim of the EU is that it seeks to transcend this realist logic, and it certainly devotes considerable effort to doing so. Unfortunately, when it came

${ }^{82}$ Biden's comments were made at the John F. Kennedy Jr Forum at Harvard University's Institute of Politics on 2 Oct. 2014. He noted the EU's reluctance to move from individual to sectoral sanctions: 'It was America's leadership and the president of the United States insisting, oft times almost having to embarrass Europe to stand up and take economic hits to impose costs', that got them to agree. 'Biden says US “embarrassed" EU into sanctioning Russia over Ukraine', RT Question More, 3 Oct. 2014, http://rt.com/usa/193044-us-embarrass-eu-sanctions/, accessed 5 April 2015.

83 'Foreign Minister of the Russian Federation Sergey Lavrov's interview with TV Channel France 24', Moscow, 16 Dec. 2014, http://www.mid.ru/brp_4.nsf/0/AEB8DD305080A07EC3257DB000514786, accessed 5 April 2015. Lavrov condemned the 'bloc discipline' in the Atlantic community, which he argued was 'stricter than the discipline that existed within the Warsaw Treaty Organisation': 'Russia's Lavrov gives interview to state TV', 25 Dec. 2014, ministry transcript of 30 Dec. 2014, http://www.mid.ru/brp_4.nsf/0/36876154732F3005C3257DBB0030AC90, accessed 6 January 2015. $\{?\}$.

84 'Russian foreign minister: we are not interested in alienation or confrontation between Russia, West', Interfax, 29 Dec. 2014.

${ }^{85}$ Angela E. Stent, The limits of partnership: US-Russian relations in the twenty-first century (Princeton: Princeton University Press, 2014). 
to dealing with the new eastern Europe, a geopolitical dynamic became apparent. In part this was a response to Russia's own claims of a certain droit de regard over the region; but there were others drivers at work, not least the changing character of EU policy as a result of the various accessions, but above all the lack of a strategic greater European vision.

The EU is not organizationally geared up for geopolitical contestation, and thus during the Ukraine crisis it soon took the back seat to a power that is precisely configured to wage geopolitical struggles on a global scale. The Ukraine crisis exposed the EU's lack of coherent agency and significant underinstitutionalization when it came to the big questions of European security. The EEAS was woefully understaffed as it grappled with the Ukrainian crisis in 201314, and Ashton, despite her best endeavours, failed to articulate a specifically European approach to the crisis. Only from 1 November 2014, with the appointment of Federica Mogherini as the new High Representative and Vice-President in the Jean-Claude Juncker Commission, was the EEAS organizationally remoulded and the Ukrainian desk significantly bolstered. Mogherini launched a review of the Eastern Partnership as well as the European security strategy, which had originally been formulated by Javier Solana over a decade earlier. This was accompanied by a discussion about the degree to which the EU needed to think more 'geopolitically', although it was not clear how this was to be defined. If it meant a realist engagement with the world as it is rather than the transdemocratic anticipation of a reality yet to be created, then traditional forms of diplomacy and bargaining could be restored. However, if it meant more explicit contestation for influence over the neighbourhood, then the era of conflict will continue.

One of the fundamental questions facing the EU as it examined its handling of the Ukraine crisis was the degree to which its norms of peace and development had been subverted by its lack of autonomy from its geopolitical ally. The question was posed in the sharpest terms possible: had the geopolitical logic of Atlanticism trumped the normative 'post-modern' aspirations of the EU? The United States is concerned to maintain its global leadership as the defender of the norms of liberal internationalism and to ensure that challenges to its leadership throughout the world are negated. ${ }^{86}$ These are classic geopolitical goals, although couched in the language of liberal

\footnotetext{
${ }^{86}$ The White House's National Security Strategy 2015 refers to American 'leadership' 36 times in the 32-page document:
} 
universalism. Whether US leadership is ultimately capable of delivering the international public goods which justify its claims to hegemonic leadership is a question this article does not address, although clearly a growing bloc of countries are uncomfortable not so much with American claims as with the typically cack-handed and destructive manner of their assertion. A similar argument can now be applied to the EU. The EU was originally established for very different purposes, namely to restore the nation-states devastated at the end of the Second World War and to ensure that they never again came into conflict with one another. ${ }^{87}$ This the EU has achieved in a spectacularly successful manner, while mostly respecting the autonomy of the member states. ${ }^{88}$ However, with the fall of the Berlin Wall in 1989 and the associated end of the Cold War, it was confronted by an even greater challenge. This was to find a way to achieve the political unification of the continent, now made up of areas with enormously different levels of development and historical experiences.

Although flanked by the Council of Europe and the OSCE, the EU remains the pre-eminent organization representing the new Europe. While beset more than ever by numerous problems, including the economic consequences of monetary union, the loss of trust by its own citizens and the increasingly unbalanced predominance of Germany, the EU remains the most successful regional integration association in human history. The fundamental paradox is that a body that has 'Europe' in its name has increasingly lacked a European vision. It came to see its own enlargement as the answer to the problems of Europe, rather than considering ways in which it could contribute to the resolution of the problems facing Europe as one actor among many. This solipsistic introspection reinforced the hermeticism of the new Atlanticism. Enlargement inevitably came up against two major problems: the lack of infinite elasticity of EU institutions; and the EU's failure to devise a genuinely continental programme of unification. The latter would have required some imaginative rethinking of European architecture and normative

http://www.whitehouse.gov/sites/default/files/docs/2015_national_security_strategy.pdf, accessed 5 April 2015.

${ }^{87} \mathrm{Cf}$. Alan Milward, The European rescue of the nation state, 2nd edn (London and New York: Routledge, 2000).

${ }^{88}$ Christopher Bickerton, European integration: from nation states to member states (Oxford: Oxford University Press, 2012). 
practices to ensure that the transformative role of the EU could be adapted to new circumstances. Instead, the single-minded focus on the EU as the supreme representation of a monist vision of wider Europe in the end provoked division and war.

Thus Europe is now faced by two fundamental interlocking challenges. The first is the crisis in the internal development of the EU and its identity, seen at its sharpest in the attempt to manage the tensions and contradictions provoked by the establishment of monetary without fiscal union, as well as widespread popular disillusionment with the idea of European integration in its entirety accompanied by the rise of various populist challenges ${ }^{89}$ European publics have simply not been given a coherent answer to the question about what the EU is for in conditions of its effective absorption into the Atlantic alliance system. This is not to say that there are not good answers, but they need to be articulated as answers not to Atlantic but to European problems. Equally, as Maxine David notes: 'The EU cannot escape the fact that Russia does not perceive it in benign terms and this must guide its policy response.' The 'need to reconceptualise the EURussia relationship . . . will require the EU to look beyond its dominant ideological inclinations'. She stresses that this does not mean granting Russia an effective veto over EU affairs or the repudiation of its normative foundations, but it does mean that 'the EU should continue to offer space for dialogue', including consideration of whether the existing 'European security architecture, of which the EU is part, is fit for purpose and whether it is overly inclusive or exclusive' ${ }^{90}$

This leads us to the second fundamental crisis, the geopolitical one. This has long been brewing, but in recent years has been overshadowed by the crisis of identity, purpose and coherence of the EU itself. In geographical terms, Europe has now entered the long-anticipated finalité, facing a crisis of enlargement in Turkey, in the Balkans and above all in the contested borderlands between the Baltic and the Black Sea. Although negotiations for the EU-Ukraine Association Agreement were begun in 2007, before the Eastern Partnership had taken shape, confrontation over its regional implications ultimately represented a spectacular failure to establish a framework for interregional cooperation and engagement. As the House of Lords report into EU-

\footnotetext{
${ }^{89}$ Peter A. Hall, 'Varieties of capitalism and the euro crisis', in Hansen, ed., Europe's crisis: background, dimensions, solutions, pp. 1223-43.

${ }^{90}$ David, 'EU-Russia relations', p. 7.
} 
Russia relations puts it, there was a high degree of 'sleep-walking' into the crisis, member states being taken by surprise by the turn of events. ${ }^{91}$ Unlike most previous accession countries, Ukraine enjoyed no demonstrable national consensus in favour of the Atlanticist turn, with a significant part of the population seeking to retain historic links with Russia. The issue is not so much Ukraine's sovereign choice to decide, as that this choice does not take place in a vacuum. Societal divisions were not given adequate political expression as the polity experienced a catastrophic breakdown, and the inherent pluralism of the country was reduced to some binary assertions, which today have become even starker.

Instead of Russia becoming a member of NATO or the dissolution of NATO to create a new military and political alliance with Russia as a founding member, the original Atlantic alliance advanced to Russia's borders. A monist logic came to predominate in Moscow, Brussels and Washington, with an entirely predictable outcome. Regarding the EU, Kissinger notes that: 'The European Union must recognize that its bureaucratic dilatoriness and subordination of the strategic element to domestic politics in negotiating Ukraine's relationship to Europe contributed to turning a negotiation into a crisis. Foreign policy is the art of establishing priorities. ${ }^{92}$ This region is far from being a 'vacuum'; it is a zone in which existing regional affiliations are strongly entrenched. Even though Ukraine had never formally ratified the Commonwealth of Independent States (CIS) Charter, the country benefited greatly from its public goods-visa-free travel, labour mobility, cross-border pension payments and much else-and ultimately from the intensification of the CIS free trade zone. Even the most benign regime in Moscow would expect substantive 'interregional' negotiations to mediate the shift in strategic orientation of the new eastern Europe as it became an area of shared involvement with the EU. Instead, there was no

\footnotetext{
${ }^{91}$ House of Lords European Union Committee, The EU and Russia: before and beyond the crisis in Ukraine, $6^{\text {th }}$ report of session 2014-2015, HL Paper 115\{?\} (London: The Stationery Office, 20 Feb. 2015), pp. 6, 63, 97.

${ }^{92}$ Henry Kissinger, 'Henry Kissinger: to settle the Ukraine crisis, start at the end', Washington Post, 5 March 2014, http://www.washingtonpost.com/opinions/henry-kissinger-to-settle-theukraine-crisis-start-at-the-end/2014/03/05/46dad868-a496-11e3-8466-d34c451760b9_story.html, accessed 5 April 2015.
} 
serious dialogue over these issues, while ideas for complementary and inclusive models for European development were too often dismissed as attempts to split the Atlantic system. The cold peace that dominated European politics for the quarter-century following the fall of the Berlin Wall in 1989 represented a type of mimetic Cold War, in which the structures and attitudes of the Cold War were perpetuated, although recognition of the fact was suppressed under a cloud of well-meaning but ultimately divisive rhetoric. Equally, the EU ultimately stumbled into geopolitical competition with Russia while suppressing recognition of the 'power' logic of its actions. Ukraine was divided internally and located along Europe's traditional historical fault-lines, but adroit diplomacy of the traditional 'realist' kind could have averted the crisis. The EU suppressed recognition of its own geopolitical ambitions, couching its advance in the language of regulation, good governance and normative institutions. These are important and fundamental goods, but their assertion without recognition of the internal and external complexities of the target country represents geopolitical nihilism of the highest order. This nihilism was couched in the language of an amorphous Atlanticism that, like the mimetic Cold War, displaced responsibility to what has now become the hermetic ideology of transdemocracy, where democratic advance is associated with subordination to the security structures of the new Atlanticism. The EU is in danger of being subsumed into the new Atlanticism, thereby losing its autonomous sense of purpose and responsibility. Instead of advancing the peaceful integration of Europe on a clearly articulated pan-continental basis, the EU became the unwitting instrument for new dividing lines across the continent. The Europe born of the end of the Cold War has died, but a new Europe combining its Euro-Atlantic and Euro-Asian identities is waiting to be born. 